\title{
Linear vs. piecewise Weibull model for genetic evaluation of sires for longevity in Simmental cattle
}

\author{
doi: $10.15567 / \mathrm{mljekarstvo.2014.0301}$ \\ Nikola Ragužz*, Sonja Jovanovac ${ }^{1}$, Gábor Mészáros², Johann Sölkner ${ }^{3}$ \\ ${ }^{1}$ Josip Juraj Strossmayer University of Osijek, Faculty of Agriculture, \\ Department for Special Zootechnics, Kralja Petra Svačića 1d, 31000 Osijek, Croatia \\ ${ }^{2}$ The Roslin Institute, The University of Edinburgh, Easter Bush, Midlothian, EH25 9RG, Scotland, UK \\ ${ }^{3}$ University of Natural Resources and Life Sciences, Department of Sustanaible Agricultural Systems, \\ Gregor Mendel Strasse 33, A-1180 Vienna, Austria \\ Received - Prispjelo: 17.04.2014. \\ Accepted - Prihvaćeno: 15.07.2014.
}

\begin{abstract}
This study was focused on genetic evaluation of longevity in Croatian Simmental cattle using linear and survival models. The main objective was to create a genetic model that is most appropriate to describe the longevity data. Survival analysis, using piecewise Weibull proportional hazards model, used all information on the length of productive life including censored as well as uncensored observations. Linear models considered culled animals only. The relative milk production within herd had a highest impact on cows' longevity. In comparison of estimated genetic parameters among methods, survival analysis yielded higher heritability value (0.075) than linear sire (0.037) and linear animal model (0.056). When linear models were used, genetic trend of Simmental bulls for longevity was slightly increasing over the years, unlike a decreasing trend in case of survival analysis methodology. Average reliability of bulls' breeding values was higher in case of survival analysis. The rank correlations between survival analysis and linear models bulls' breeding values for longevity were ranged between 0.44 and 0.46 implying huge differences in ranking of sires.
\end{abstract}

Key words: longevity, genetic evaluation, linear models, piecewise Weibull model, Simmental cattle

\section{Introduction}

The ability to produce and reproduce well for many years is a desirable characteristic in dairy cattle, both from an economic and breed improvement perspective. An increased longevity is associated with reduced replacement costs and increased proportion of mature, high producing cows in a herd. In addition, breeding for increased longevity is more ethical because the selection is aimed at improvement of health and fitness, i.e. well being of the cow and not at productivity only.

Considering longevity in breeding programs and genetic evaluation of animals for this trait are generally challenging. The main difficulty is that a part of the animals is still alive in the moment of genetic evaluation and only the lower bound of their eventual productive life is known. To exlcude these records from the evaluation or consider them as exact would lead to biased results. This problem can be solved by using survival analysis (Ducrocq et al., 1988; Vukasinovic et al., 2001). This method uses both information of those animals that are still alive and productive (censored) as well as of those animals that were culled (uncensored). It also allows for taking into account the change of culling policies and environmental effects by treating them as timedependent effects (Ducrocq et al., 1988).

Another difficulty associated with genetic evaluation for longevity is that the overall longevity 
results from a product rather than from a sum of effects influencing the trait (Beilharz et al., 1993); when at least one of them is defective, the longevity of an animal is impaired (Ducrocq and Sölkner, 1998). Therefore, traditional methods for genetic evaluation based on linear models, such as BLUP, although widely used in some countries cannot properly account for nonlinearity of longevity data (Vukasinovic et al., 1999). In addition, heritability estimates for longevity resulting from Weibull proportional hazards model generally range from 0.05 up to 0.20 as compared with 0.05 to 0.10 from conventional linear models, although these values are not directly comparable (Yazdi et al., 2002, Serenius and Stalder, 2004; Mészáros et al., 2010). Curiously, comparisons between survival analysis and linear models methodolgy based on actual life data in Simmental cattle are lacking in the animal breeding literature.

The objectives of this research were two-folded: the first was to estimate heritabilities and breeding values for longevity of Simmental cattle using linear and survival models; the second was to compare results obtained by different methods using rank correlations between sires' breeding values.

\section{Material and methods}

Longevity data and production records were provided by Croatian Agricultural Agency (HPA) and collected on December 31, 2011. After adequate data preparation, records from 89,209 Simmental cows with first calving from January 1993 through July 2011 remained for analysis. All cows were required to have valid sire, paternal grandsire and granddam identification as well as age at first calving between 20 and 40 months. The total number of herds assigned to 4 geographical regions was 14,927 , comprising herds with average size of only 6.3 cows due to deleting the animals with unknown sire pedigree (table 1). The minimum number of daughters per sire was 12 with a total number of sires of 713 .

Longevity was defined as the number of days from first calving until culling or censoring. For the animals with missing culling date, the date of the last known lactation was used where the cow was considered as culled if the number of days between the end of last lactation and the date of data collection exceeded 365 days. Otherwise, the record was considered as right censored. In total, the censoring procedure resulted in 22,694 (25.4\%) right censored cows with the minimum censoring or culling time of 91 days.

For survival analysis, the following piecewise Weibull proportional hazards model was used:

$$
\lambda(t)=\lambda_{0}(t) \exp \left(y s_{i}+r p_{j}+a f c_{k}+r e g_{l}+h s_{m}+s_{n}\right)
$$

where:

$\lambda(t)=$ hazard function (instantaneous probability of culling) for a given cow at time $t$; $\lambda_{0}(t)=$ Weibull baseline hazard function with scale parameter $\lambda$ and shape parameter $\rho$; $y s_{i}=$ random time dependent effect of year *season following a log-gamma distribution; $r p_{j}=$ the fixed time dependent effect of the relative milk production within herd; $a f c_{k}=$ the fixed time independent effect of age at first calving; reg $_{l}=$ the fixed time independent effect of region; $h s_{m}=$ the fixed time independent effect of herd size; $s_{n}=$ random time independent effect of sire. The model was stratified by parity, reseting the baseline $\rho$ to 0 for each stratum.

Table 1. Number of herds, cows and sires per region

\begin{tabular}{lccccc}
\hline Region & $\begin{array}{c}\text { Number of } \\
\text { herds/farmers }\end{array}$ & $\begin{array}{c}\text { Number } \\
\text { of cows }\end{array}$ & $\begin{array}{c}\text { Average herd } \\
\text { size }\end{array}$ & $\begin{array}{c}\text { Number of } \\
\text { sires }\end{array}$ & $\begin{array}{c}\text { Average number of } \\
\text { daughters per sire }\end{array}$ \\
\hline Eastern Croatia & 3,638 & 22,466 & 6.2 & 621 & 36 \\
\hline North-Western Croatia & 7,644 & 39,900 & 5.2 & 625 & 64 \\
\hline Upland Croatia & 3,201 & 24,177 & 7.6 & 585 & 41 \\
\hline Mediterranean Croatia & 444 & 2,666 & 6.0 & 263 & 10 \\
\hline Total & $\mathbf{1 4 , 9 2 7}$ & $\mathbf{8 9 , 2 0 9}$ & 6.3 & 713 & 125 \\
\hline
\end{tabular}


For estimation of the standard lactation milk yield, the Test interval method approved by ICAR (2009) was used. To account for culling for production, the effect of within herd production level was included, which resulted into estimation of the functional productive life. The relative milk production in each lactation was calculated after their adjustment to the first lactation, as the milk production of a cow was compared to the herd average in the given year. The resulting difference was expressed in standard deviations and divided into 9 classes. The effect of the herd size was taken into account using 4 classes. The highest proportion of the cows was from small herds less than 6 animals. Other animals were divided into classes $\geq 6$ and $<10, \geq 10$ and $<15$ and $\geq 15$.

The cows were grouped according to the slightly different climatic conditions in 4 groups covering the four main Croatian regions. According to the age of first calving, cows were divided in 7 different classes. The year*season effect was taken into account through 3 seasons, where the periods from January to April, May to September and October to December represented seasons 1 to 3 , respectively.

In case of linear models, the same effects were used except the effect of region due to non-significant influence on the length of productive life (LPL). Effects as level of production and interaction between year and season of calving were taken into account as time independent variables, i.e. only the first lactation values because of inability of linear models to handle the time dependent variables. Therefore, the following linear model was used:

$$
\mathrm{Y}_{\mathrm{ijklm}}=\mathrm{rp}_{\mathrm{i}}+\mathrm{afc}_{\mathrm{j}}+\mathrm{ys}_{\mathrm{k}}+\mathrm{g}_{\mathrm{l}}+\mathrm{e}_{\mathrm{ijklm}}
$$

where: $Y_{\mathrm{ijklm}}=$ LPL in days; $\mathrm{rp}_{\mathrm{i}}=$ the fixed effect of relative milk production in $1^{\text {st }}$ lactation; $\mathrm{afc}_{\mathrm{j}}=$ the fixed effect of age at first calving; $\mathrm{ys}_{\mathrm{k}}=$ random effect of year* season of $1^{\text {st }}$ calving; $g_{1}=$ random genetic effect of sire or animal; $\mathrm{e}_{\mathrm{ijklm}}=$ error.

The heritability using survival analysis was calculated as proposed by Yazdi et al. (2002):

$$
\mathrm{h}^{2}=4 \sigma_{\mathrm{s}}^{2} /\left[\sigma_{\mathrm{s}}^{2}+\sigma_{\mathrm{ys}}{ }^{2}+(1 / \mathrm{p})\right]
$$

where: $h^{2}=$ the coefficient of heritability for functional LPL; $\sigma_{s}^{2}=$ the genetic variance of sires; $\sigma_{\mathrm{ys}}{ }^{2}=$ year*season variance, $\mathrm{p}=$ the proportion of uncensored records.

Using linear models, the heritability was calculated using following formulas: $h^{2}=4 \sigma_{\mathrm{s}}{ }^{2} /\left[\sigma_{\mathrm{s}}{ }^{2}+\sigma_{\mathrm{ys}}{ }^{2}+\sigma_{\mathrm{e}}{ }^{2}\right]$ for sire model, and $\mathrm{h}^{2}=$ $\sigma_{\mathrm{a}}^{2} /\left[\sigma_{\mathrm{a}}^{2}+\sigma_{\mathrm{ys}}^{2}+\sigma_{\mathrm{e}}^{2}\right]$ for animal model, where:

$h^{2}=$ the coefficient of heritability for functional LPL; $\sigma_{s}^{2}=$ the genetic variance of sires; $\sigma_{\mathrm{a}}^{2}=$ additive genetic variance; $\sigma_{\mathrm{ys}}{ }^{2}=$ year* season variance; $\sigma_{\mathrm{e}}{ }^{2}$ $=$ residual variance.

Breeding values for functional LPL were computed using these parameter estimates. Average breeding values were calculated compared to the mean and standard deviation of the group of base sires, with birth year between 1996 and 2000. The following equation for breeding value computation was used:

$$
\mathrm{BV}=\{[(\text { estimate }-\mathrm{a}) / \mathrm{sd}] *(-12)\}+100
$$

where:

$\mathrm{BV}=$ the breeding value of a sire; estimate $=$ the regression coefficient estimate for a particular bull; $\mathrm{a}=$ the mean of estimates in the group of base sires; $\mathrm{sd}=$ the standard deviation of estimates of base sires. The minus sign (used for survival model only) represents the alternation of breeding values to express longer productive life with higher values.

Reliability values for each bull using survival model and linear sire model were computed according to Ducrocq (1999):

$$
\mathrm{R}=\mathrm{n} /\left\{\mathrm{n}+\left[\left(4-\mathrm{h}^{2}\right) / \mathrm{h}^{2}\right]\right\}
$$

where: $\mathrm{R}=$ the value of the reliability; $\mathrm{n}=$ the number of uncensored daughters of a bull; $h^{2}=$ the estimated heritability of functional LPL.

In case of linear animal model, the following formula was used:

$$
\mathrm{R}=\sqrt{1-P E V_{i} / \sigma_{a}^{2}} \text {, where: }
$$

$\mathrm{R}=$ the value of reliability; $\mathrm{PEV}_{\mathrm{i}}=$ prediction error variance; $\sigma_{\mathrm{a}}^{2}=$ additive genetic variance.

The rank correlations between survival and linear bulls' breeding values were calculated using Spearman correlation coefficient. For survival analysis, the software Survival Kit V6.12 (Ducrocq et al., 2010) was used, while for the linear models VCE V6.0 (Groeneveld et al., 2010) and PEST (Groeneveld et al., 2007) were used. The initial textual files were prepared using SAS 9.1. 


\section{Results and discussion}

Average LPL of all Simmental cows included in data analysis was 2.88 years while the average number of parities was 2.55 (table 2).

The highest proportion of animals was culled after the $1^{\text {st }}$ lactation (33.4\%). The number of cullings decreased in consecutive lactations and resulted with only $1.15 \%$ of cows that were culled after the $7^{\text {th }}$ lactation. Boettcher et al. (1999) and Caraviello et al. (2004) found similar trends in cullings of cows through parities, where $74.1 \%$ and $65 \%$ of all analysed cows survived the first lactation and started the second one. The farmers tend to cull animals with very low milk production or reproduction performance in the first half of first lactation most frequently, with the aim to avoid additional costs, as found by Mészáros et al., 2008. High proportion of early cullings in Croatia could be the consequence of high selection pressure for the milk production in first lactation as well as possible reproduction and other health disorders. The piecewise Weibull model used for the analysis of the length of productive life comprised seven effects including time independent and time dependent effects. Many authors consider milk production as a key factor in culling decisions (Vollema et al., 2000; Vukasinovic et al., 2001; Sewalem et al., 2005; Mészáros et al., 2008; Bonetti et al., 2009). According to the data structure of Croatian Simmental population, milk production was taken into account through 9 classes of standard deviations in range from $<-1.5$ to $>+1.5$ from average herd production. The results indicate a clear trend of culling risks where the highest risks were obtained for animals with lowest production (3.1 times higher) and vice versa. That kind of trend is evident in other studies (Páchová et al., 2005, Chirinos et al., 2007, Mészáros et al., 2008, Bonetti et al., 2009) and confirms our results.

Unlike other studies, where parity and lactation stage were analysed like an interaction effect, this study considered the effect of parity only. The main reason for this was no cullings found during the first 150 days of the $1^{\text {st }}$ lactation, so consideration of lactation stage effect would make no sense. The effect of parity was used as a stratification variable due to very high variances obtained in case when parity was considered as a fixed time dependent effect. The $\rho$ values (baseline hazard) ranged from 3.17 in $1^{\text {st }}$ to 2.35 in $6^{\text {th }}$ lactation, in average around 2.7 (Table 3 ). In addition, in case of considering parity as a non-stratificication variable, the $1^{\text {st }}$ parity $\rho$ values exceeded the values of 5.0, that overestimated the culling risks in $1^{\text {st }}$ lactation. Similar stratification procedure was used in French model for genetic evaluation of dairy bulls (Ducrocq, 2005), where year and parity were used as strata variables.

Age at first calving had a very small influence on the LPL which is in accordance with most other studies (Dürr et al., 1999; Vollema et al., 2000; Caraviello et al., 2004; Páchová et al., 2005).

The effect of region had a small but significant effect on the length of productive life where the highest culling risks were found in North-West region. This region is traditionally oriented to cattle breeding, especially of Simmental cattle, hence such results were expected probably due to higher

Table 2. Descriptive statistics for the LPL, number of parities, age at first calving and milk yield

\begin{tabular}{lccccc}
\hline Trait & Average & SD & CV & Min & Max \\
\hline $\begin{array}{l}\text { Length of productive life } \\
\text { (years) - all data }\end{array}$ & 2.88 & 1.75 & 60.7 & 0.13 & 8.22 \\
\hline $\begin{array}{l}\text { Length of productive life } \\
\text { (years) - uncensored data }\end{array}$ & 2.75 & 1.71 & 61.8 & 0.13 & 8.22 \\
\hline $\begin{array}{l}\text { Length of productive life } \\
\text { (years) - censored data }\end{array}$ & 3.26 & 1.83 & 56.3 & 0.25 & 8.22 \\
\hline Number of parities & 2.55 & 1.57 & 61.6 & 1 & 7 \\
\hline Age at first calving & 26.92 & 3.42 & 12.7 & 20 & 40 \\
\hline Lifetime milk yield, $\mathrm{kg}$ & 10,511 & 7,049 & 67.1 & 800 & 50,382 \\
\hline
\end{tabular}


Table 3. Parameters estimated for the piecewise Weibull model

\begin{tabular}{lc}
\hline Parametar & Estimated value \\
\hline$\rho$ - baseline hazard ${ }^{1}$ & 2.66 \\
\hline Log-gamma, $\gamma$ & 4.50 \\
\hline Year*season variance, $\sigma_{\mathrm{y}}^{2}$ & 0.24 \\
\hline Sire variance, $\sigma_{\mathrm{s}}^{2}$ & 0.03 \\
\hline Additive genetic variance, $\sigma_{\mathrm{a}}^{2}=4 \sigma_{\mathrm{s}}^{2}$ & 0.12 \\
\hline Heritability, $\mathrm{h}^{2}$ & 0.075 \\
\hline
\end{tabular}

${ }^{1}$ Average value of 7 strata

selection pressure by comparison with other regions. Effect of region was analysed in several other studies (Smith et al., 2000; Vukasinovic et al., 2001; Ducrocq, 2005; Chirinos et al., 2007) where significant differences in LPL were found among regions.

The herd size effect as well as the effect of year*season significantly influenced cows' longevity. The highest culling risks were found for herds with more than 15 animals, where cows had 1.5 times higher culling risk than the cows from herds between 6 and 10 animals.

The estimated sire variance for the LPL of their daughters using piecewise Weibull model was 0.03 (Table 3). Expressed as heritability, a value of 0.075 was calculated.

The Weibull parameter $\rho$ was equal to 2.66 that clearly indicates increase of risk as age increases. Majority of other studies found similar results of heritabilities in range from 0.04 to 0.11 (Ducrocq, 2005; Chirinos et al., 2007; Mészáros et al., 2013). In addition, Vukasinovic et al. (2001) compared heritabilities between two breeds, where higher value was determined for Simmental cattle (0.198) in compare to Holstein breed (0.184).
In order to simplify a comparison between survival and linear models, a sire model was also used for the linear model, besides an animal model. However, Ramirez-Valverde et al. (2001) found that comparing sire models and animal models might lead to a different ranking of sires. The variances obtained by both linear sire and linear animal model were higher than the variance obtained by survival analysis, but finally resulted in lower heritabilities (Table 4).

These differences between survival and linear model methodologies were probably a consequence of an inclusion of additional information from censored cows (old cows). Perhaps, some proportion of genetic variance was lost by elimination of censored records. The linear models estimated the residual variance unlike survival analysis where the heritability estimates were calculated assuming that the residual effects were following extreme value distribution with the variance $\pi^{2} / 6$ (Serenius and Stalder, 2004). Consequently, it could be questionable if the heritability values between different methods are comparable. According to other studies, the genetic parameters obtained by survival models were higher than those obtained by modifications of linear

Table 4. Parameters estimated using linear sire and animal models

\begin{tabular}{lcccccc}
\hline & \multicolumn{6}{c}{ Parameter } \\
\cline { 2 - 7 } Model & $\sigma^{2}{ }_{\mathrm{s}}$ & $\sigma_{\mathrm{g}}^{2}$ & $\sigma^{2}{ }_{\mathrm{e}}$ & $\sigma_{{ }_{\mathrm{a}}{ }^{2}\left(4 \sigma_{\mathrm{s}}{ }_{\mathrm{s}}\right)}$ & $\mathrm{h}^{2}$ & $\mathrm{SE}_{\mathrm{h}}{ }^{2}$ \\
\hline Sire model & $3,777.17$ & $70,886.9$ & 332,824 & $15,108.68$ & 0.037 & 0.0056 \\
\hline Animal model & - & $69,976.9$ & 315,031 & $22,936.5$ & 0.056 & 0.0082 \\
\hline
\end{tabular}

$\sigma^{2}$ - sire variance; $\sigma^{2}$ - year*season variance; $\sigma^{2}$ - residual variance; $\sigma_{a}^{2}$ - additive genetic variance;

$\mathrm{h}^{{ }^{\mathrm{s}}}$ - heritability; $\mathrm{SE}_{\mathrm{h}}{ }^{\mathrm{g}}$ - standard error of heritability 


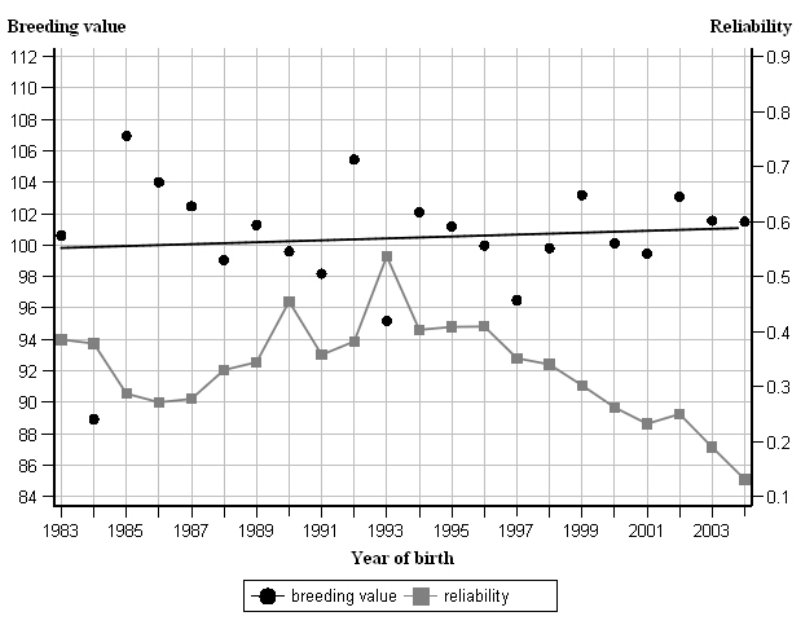

Figure 1. Genetic trend for longevity (linear sire model)

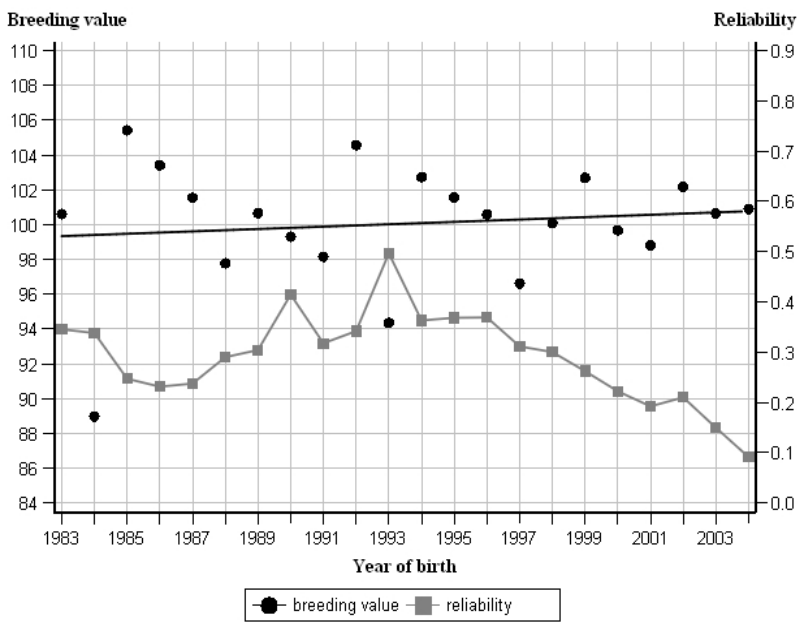

Figure 2. Genetic trend for longevity (linear animal model)

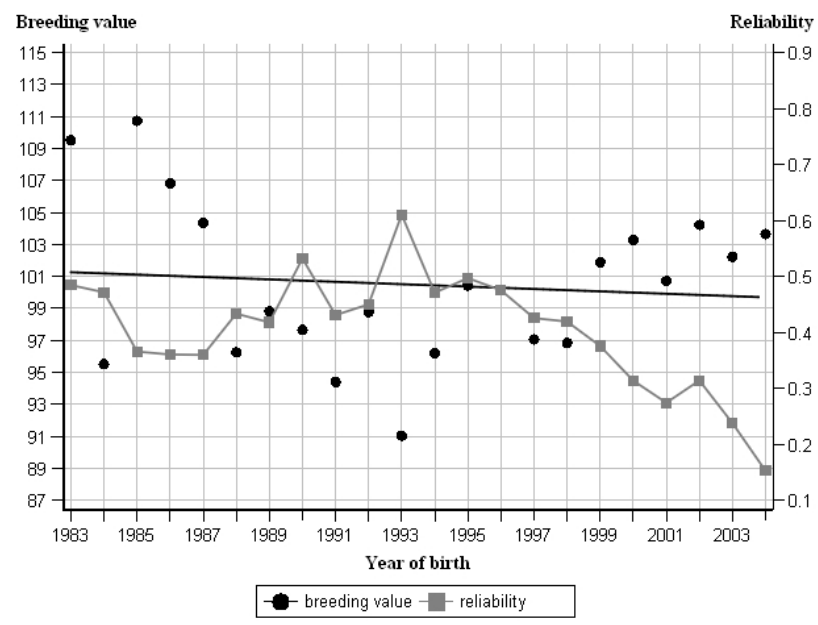

Figure 3. Genetic trend for longevity (piecewise Weibull model) models (Boettcher et al., 1999, Caraviello et al., 2004; Forabosco et al., 2006; Potočnik et al., 2008). Key reasons for this are better suitability of survival methodology in analysis of longevity data due to inclusion of records on animals that are still alive, as well as ability to account for the time dependent variables such as year*season of calving and relative milk production within herd. Moreover, survival analysis can give more precise sires' breeding values without losing useful information. It means that our results on ranking of sires was different depending on used methodology. Calculated reliabilites of breeding values were higher in case of survival analysis where average reliability of $38 \%$ was found for sires with 32 uncensored daughters. Linear models yielded lower reliabilites of 27 $\%$ and $31 \%$ for sire and animal models respectively. The genetic trends of bulls for longevity of their daughters as well as reliabilities for each year are shown in figures 1,2 and 3.

The minimum number of sires born per year was 5 where the reference group of bulls was born between 1996 and 2000. The reliability of breeding values depends on the number of uncensored records and is very low for young sires having only few uncensored daughters.

Increasing the reliability of breeding values for young sires will be one of the most important tasks for the population of Simmental bulls in Croatia in the future.

In a case when a young sire has no uncensored daughters, the reliability of his breeding value is based on pedigree information only ( $\mathrm{Vu}$ kasinovic et al., 2001). The reliability could be increased by taking weighted information on censored daughters into account as well as by the inclusion of information from early predictors (type traits, somatic cell count and fertility). When calculating the correlations between sires' breeding values for longevity using different methods, only sires present in the linear and survival analysis with at least 25 uncensored daughters were used; 25 was chosen because it was the average number of daughters in three main regions (except Mediterranean region).

In this way it was possible to compare 371 sires with relatively high reliabilities (Table 5). 
Table 5. Estimated heritabilities (diagonal), Spearman's rank correlations (above diagonal) and Pearson's correlations (below diagonal) between estimated sires breeding values using different methods

\begin{tabular}{cccc}
\hline Model & Piecewise Weibull & Linear sire & Linear animal \\
\hline Piecewise Weibull & $\mathbf{0 . 0 7 5}$ & 0.44 & 0.46 \\
\hline Linear sire & 0,43 & $\mathbf{0 , 0 3 7}$ & 0,99 \\
\hline Linear animal & 0,46 & 0,99 & $\mathbf{0 , 0 5 6}$ \\
\hline
\end{tabular}

Moderate correlations were found between Weibull and linear models $(0.44-0.46)$ while correlations between linear sire and animal models were almost full (0.99). It proves respectable distinction in ranking of sires by use of linear and non-linear models giving preference to non-linear models due to above mentioned reasons. Similar results were found by Caraviello et al. (2004) where correlations between survival and animal models ranged between 0.35 and 0.60 , depending on randomly choosen sample of animals. Medium to very high correlations ranging between 0.70 and 0.90 were found by Boettcher et al. (1999) and Forabosco et al. (2006). The lowest correlations were found by Potočnik et al. (2008) of only 0.15 between linear sire and survival model, and 0.17 between linear animal and survival model.

\section{Conclusions}

The highest impact on longevity was found for the level of production, where the cows with lowest production had 3.1 times higher risk to be culled than the cows with average production within same herd. Heritability estimates were different using survival and linear models. The highest estimate (0.075) was calculated using survival analysis including both censored (25.4\%) and uncensored records while the lowest estimate was obtained using linear sire model (0.035). The average sires' breeding values reliabilities were higher using survival analysis (37\%) in compare to linear sire and animal models (27\% to $31 \%$ respectively). The rank correlation indicated a clear difference in ranking of sires by their survival and linear models breeding values for longevity. A priority will be given to survival analysis due to optimally handling of censored and uncensored data as well as ability to deal with time dependent events.

\section{Usporedba linearnog i "piecewise" modela po Weibullu u genetskom vrednovanju bikova za dugovječnost u populaciji simentalske pasmine goveda}

\section{Sažetak}

Glavni ciljevi ovoga istraživanja bili su genetsko vrednovanje dugovječnosti simentalskih bikova u Hrvatskoj pomoću metode analize preživljavanja i linearnih mješovitih modela te usporedba korištenih metoda. Analizom preživljavanja, temeljenom na piecewise Weibull modelu proporcionalnih rizika korišteni su svi dostupni podaci o trajanju produktivnog vijeka krava, uključujući i krave koje se još uvijek nalaze u proizvodnji i čiji datum izlučenja nije bio poznat $u$ trenutku završetka istraživanja. U slučaju modifikacija linearnih modela, razmatrane su samo izlučene životinje. Uspoređujući primijenjene metode, analiza preživljavanja rezultirala je višim vrijednostima heritabiliteta (0.075) u odnosu na linearni model oca $(0.035)$ kao i na individualni linearni model (0.056). Genetski trend bikova za dugovječnost imao je rastući karakter (linearni modeli), dok je uporabom analize preživljavanja genetski trend bio opadajući. Prosječne pouzdanosti procijenjenih uzgojnih vrijednosti bikova za dugovječnost na temelju linearnih modela bile su niže u odnosu na iste procijenjene piecewise Weibull modelom proporcionalnih rizika. Korelacije ranga između uzgojnih vrijednosti bikova procijenjenih različitim metodama kretale su se u rasponu od 0.44 do 0.46 .

Ključne riječi: dugovječnost, genetsko vrednovanje, linearni modeli, "piecewise" model po Weibullu, simentalsko govedo 


\section{References}

1. Beilharz, R.G., Luxford, B.G., Wilkinson, J.I. (1993): Quantitative genetic and evolution: Is our understanding of genetic sufficient to explain evolution? Journal of Animal Breeding and Genetics 110, 161-170. doi: dx.doi.org/10.1111/j.1439-0388.1993.tb00728.x

2. Boettcher, P.J., Jairath, L.K., Dekkers, J.C.M. (1999): Comparison of methods for genetic evaluation of sires for survival of their daughters in the first three lactations. Journal of Dairy Science 82, 1034-1044. doi: dx.doi.org/10.3168/jds.S0022-0302(99)75324-5

3. Bonetti, O., Rossoni, A., Nicoletti, C. (2009): Genetic parameters estimation and genetic evaluation for longevity in Italian Brown Swiss bulls. Italian Journal of Animal Science 8, 30-32.

4. Caraviello, D.Z., Weigel, K.A., Gianola, D. (2004): Comparison between a Weibull proportional hazards model and a linear model for predicting the genetic merit of US Jersey sires for daughter longevity. Journal of Dairy Science 87, 1469-1476. doi: dx.doi.org/10.3168/jds.S0022-0302(04)73 298-1

5. Chirinos, Z., Carabaňo, M.J., Hernandez, D. (2007): Genetic evaluation of length of productive life in the Spanish Holstein-Friesian population. Model validation and genetic parameters estimation. Livestock Science 106, 120-131. doi: dx.doi.org/10.1016/j.livsci.2006.07.006

6. Ducrocq, V., Quass, R.L. Pollak, E.J., Casella, G. (1988): Length of productive life in dairy cows: 2. Variance component estimation and sire evaluation. Journal of Dairy Science 71, 3071-3079. doi: dx.doi.org/10.3168/jds.S0022-0302(88)79907-5

7. Ducrocq, V., Sölkner, J. (1998): Implementation of a routine breeding value evaluation for longevity of dairy cows using survival analysis techniques. Proceedings of the $6^{\text {th }}$ World Congress on Genetics Applied to Livestock Production, Armidale, Australia, 23, 359-362.

8. Ducrocq, V. (1999): Two years of experience with the French genetic evaluation of dairy bulls on production adjusted longevity of their daughters. Proc. Int. Workshop on EU Concerted Action Genetic Improvement of Functional Traits in Cattle; Longevity. Jouy-en-Josas, France, INTERBULL Bull. 21.

9. Ducrocq, V. (2005): An improved model for the French genetic evaluation of dairy bulls on length of productive life of their daughters. Animal Science 80, 249-256. doi: dx.doi.org/10.1079/ASC41720249

10. Dürr, J.W., Monardes, H.G., Cue, R.I. (1999): Genetic analysis of herd life in Quebec Holsteins using Weibull models. Journal of Dairy Science 82, 2503-2513. doi: dx.doi.org/10.3168/jds.S0022-0302(99)755 02-5

11. Forabosco, F., Bozzi, R., Filippini, F., Boettcher, P., Van Arendonk, J.A.M., Bijma, P. (2006): Linear model vs. survival analysis for genetic evaluation of sires for longevity in Chianina beef cattle. Livestock Science 101, 191-198. doi: dx.doi.org/10.1016/j.livprodsci.2005.11.010
12. Groeneveld, E., Kovač, M., Wang, T. (2007): PEST, a general purpose BLUP package for multivariate prediction and estimation. Department of Animal Sciences, University of Illinois.

13. Groeneveld, E., Kovač, M., Mielenz, N. (2010): VCE v6.0. User's Guide and Reference Manual Version 6.0. ftp://ftp.tzv.fal.de/pub/vce6/doc/vce6-manual-3.1-A4. pdf.

14. ICAR - International Committee for Animal Recording (2009): Guidelines approved by the General Assembly held in Niagara Falls, USA, 18 June 2008.

15. Mészáros, G., Fuerst, C., Fuerst-Waltl, B., Kadlečík, O., Kasarda, R., Sölkner, J. (2008): Genetic evaluation for length of productive life in Slovak Pinzgau cattle. Archives of animal breeding 51, 438-448.

16. Mészáros, G., Pálos, J., Ducrocq, V., Sölkner, J. (2010): Heritability of longevity in Large White and Landrace sows using continuous time and grouped data models. Genetics Selection Evolution 42, 13. doi: dx.doi.org/10.1186/1297-9686-42-13

17. Mészáros, G., Kadlečík, O., Kasarda, R., Sölkner, J. (2013): Analysis of longevity in the Slovak Pinzgau population - extension to the animal model. Czech Journal of Animal Science 58, 289-295.

18. Mészáros, G., Sölkner, J., Ducrocq, V. (2013): The Survival Kit: Software to analyze survival data including possibly correlated random effects. Computer Methods and Programs in Biomedicine 110 (3), 503-510. doi: dx.doi.org/10.1016/j.cmpb.2013.01.010

19. Páchová, E., Zavadilová, L., Sölkner, J. (2005): Genetic evaluation of the length of productive life in Holstein cattle in the Czech Republic. Czech Journal of Animal Science 50, 493-498.

20. Potočnik, K., Krsnik, J., Štepec, M., Gorjanc, G. (2008): Comparison between methods for estimation of breeding values for longevity in Slovenian Holstein population. INTERBULL meeting, 16-19 June, Niagara Falls, NY.

21. Ramirez-Valverde, R., Misztal, I., Bertrand, J.K. (2001): Comparison of threshold vs linear and animal vs sire models for predicting direct and maternal genetic effects on calving difficulty in beef cattle. Journal of Animal Science 79, 333-338.

22. SAS Institute 2002-2003. The SAS System. Version 9.1., Cary, SAS Instituet, CD-ROM.

23. Serenius, T., Stalder, K.J. (2004): Genetics of length of productive life and lifetime prolificacy in the Finnish Landrace and Large White pig populations. Journal of Animal Science 82, 3111-3117.

24. Sewalem, A., Kistemaker, G.J., Ducrocq, V., Van Doormaal, B.J. (2005): Genetic analysis of herd life in Canadian dairy cattle on a lactation basis using a Weibull proportional hazards model. Journal of Dairy Science 88, 368-375. doi: dx.doi.org/10.3168/jds.S0022-0302(05)72696-5

25. Smith, J.W., Ely, L.O., Chapa, A.M. (2000): Effect of region, herd size, and milk production on reasons cows leave the herd. Journal of Dairy Science 83, 2980-2987. doi: dx.doi.org/10.3168/jds.S0022-0302(00)75198-8 
26. Vollema, A.R., Van Der Beek, S., Harbers, A.G.F., de Jong, G. (2000): Genetic evaluation for longevity of Dutch dairy bulls. Journal of Dairy Science 83, 2629-2639. doi: dx.doi.org/10.3168/jds.S0022-0302(00)75156-3

27. Vukasinovic, N., Moll, J., Künzi, N. (1999): Genetic evaluation for length of productive life with censored records. Journal of Dairy Science 82, 2178-2185. doi: dx.doi.org/10.3168/jds.S0022-0302(99)75462-7

28. Vukasinovic, N., Moll, J., Casanova, L. (2001): Implementation of a routine genetic evaluation for longevity based on survival analysis techniques in dairy cattle populations in Switzerland. Journal of Dairy Science 84, 2073-2080. doi: dx.doi.org/10.3168/jds.S0022-0302(01)74652-8
29. Yazdi, M.H., Visscher, P.M., Ducrocq, V., Thompson, R. (2002): Heritability, reliability of genetic evaluations and response to selection in pr portional to selection in proportional hazard models. Journal of Dairy Science 85, 1563-1577. doi: dx.doi.org/10.3168/jds.S0022-0302(02)74226-4 